University of Nebraska - Lincoln

DigitalCommons@University of Nebraska - Lincoln

Agronomy \& Horticulture -- Faculty Publications

Agronomy and Horticulture Department

July 2000

\title{
Reversal of Rice Yield Decline in a Long-Term Continuous Cropping Experiment
}

\author{
Achim Dobermann \\ International Rice Research Institute (IRRI), MCPO \\ David Dawe \\ International Rice Research Institute (IRRI), MCPO \\ Reimund P. Roetter \\ International Rice Research Institute (IRRI), MCPO \\ Kenneth G. Cassman \\ University of Nebraska-Lincoln, kcassman1@unl.edu
}

Follow this and additional works at: https://digitalcommons.unl.edu/agronomyfacpub

Part of the Plant Sciences Commons

Dobermann, Achim; Dawe, David; Roetter, Reimund P.; and Cassman, Kenneth G., "Reversal of Rice Yield Decline in a Long-Term Continuous Cropping Experiment" (2000). Agronomy \& Horticulture -- Faculty Publications. 91.

https://digitalcommons.unl.edu/agronomyfacpub/91

This Article is brought to you for free and open access by the Agronomy and Horticulture Department at DigitalCommons@University of Nebraska - Lincoln. It has been accepted for inclusion in Agronomy \& Horticulture -Faculty Publications by an authorized administrator of DigitalCommons@University of Nebraska - Lincoln. 


\title{
SOIL FERTILITY
}

\section{Reversal of Rice Yield Decline in a Long-Term Continuous Cropping Experiment}

\author{
Achim Dobermann,* David Dawe, Reimund P. Roetter, and Kenneth G. Cassman
}

\begin{abstract}
In a long-term continuous cropping experiment at Los Baños, Philippines, three rice (Oryza sativa L.) crops were grown each year with the goals of maximum annual grain production and high $\mathbf{N}$ use efficiency. Our objective was to identify the factors responsible for the restoration of yields occurring after 1991. From 1968 to 1991, grain yields declined at an annual rate of 1.4 to $2.0 \%$. From 1991 to 1995 , dry season (DS) yields in the highest $N$ treatment increased to within 80 to $100 \%$ of the simulated yield potential; yields in the unfertilized control did not increase. Increased solar radiation, increased $\mathbf{N}$ rate, and improved timing of $\mathbf{N}$ applications accounted for the restoration of yields in the DS. Wet season yields increased in fertilized and unfertilized plots due to greater solar radiation, improved timing of $\mathbf{N}$ applications, and increased soil $\mathbf{N}$ supply due to dry fallow periods in three years. Residual benefits of soil aeration were short-term. Reducing preplant $\mathbf{N}$ fertilizer and increasing the number of split applications had a greater effect on increasing yield than the increase in the amount of $\mathrm{N}$ applied. Our results provide evidence that $\mathbf{N}$ deficiency caused the yield decline before 1991 . However, the actual processes that caused a decline in soil $\mathbf{N}$ supply or plant $\mathbf{N}$ uptake remain to be determined. It is possible to sustain high yields and high $\mathbf{N}$ use efficiency if fertilizer regimes are updated regularly to maintain the congruence between crop $\mathbf{N}$ demand and the $\mathbf{N}$ supply from soil and fertilizer.
\end{abstract}

$\mathrm{T}$ HE LONG-TERM CONTINUOUS CROPPING EXPERIMENT (LTCCE) at the International Rice Research Institute (IRRI) is the longest-running experiment of triplecropped rice in the world. It was begun in 1963 to study the feasibility of continuous triple-crop rice systems made possible by short-duration, high-yielding varieties and irrigation. More than 100 crops had been harvested by 1999. From 1968 until 1991, trend yields of the highest-yielding variety in this experiment declined at an average annual rate of $1.6 \%$ in the dry season, $2.0 \%$ in the early wet season (EWS), and $1.4 \%$ in the late wet season (LWS). These are equivalent to cumulative yield declines of 44, 58, and 38\%, respectively, in 24 years (Cassman et al., 1995). Concern was raised that despite the best management practices in the LTCCE, the yield decline observed may be an indicator of a reduction in soil quality that results from continuous rice monocrop-

A. Dobermann, D. Dawe, and R.P. Roetter, International Rice Research Institute (IRRI), MCPO, P.O. Box 3127, 1271 Makati City, Philippines; K.G. Cassman, IANR, Dep. of Agronomy, Univ. of Nebraska, Lincoln, NE 68583-0915. Received 28 Sept. 1999. *Corresponding author (adobermann2@unl.edu). Current address for corresponding author: Univ. of Nebraska, IANR, Dep. of Agronomy, P.O. Box 830915, Lincoln, NE 68583-0915.

Published in Agron. J. 92:633-643 (2000). ping under flooded soil conditions (Cassman and Pingali, 1995).

Yield declines appear to be less common at sites with double cropping of rice and yield levels of 4 to $7 \mathrm{Mg}$ $\mathrm{ha}^{-1}$ (Dawe et al., 2000), a cropping system found on about 14 million ha of land area in Asia. The LTCCE, however, serves the purpose of studying the sustainability of intensive rice cropping at its greatest level of crop intensification so that trends observed in this system may be early warning indicators of what could happen in the future in farmers' fields. The objective of the LTCCE is to achieve maximum and stable annual grain production on a sustainable basis in relation to $\mathrm{N}$ fertilizer use. Therefore, starting in 1991, significant changes in crop management were made to reverse the yield decline and to achieve yield levels that approach the yield potential of modern rice varieties. In this paper, we attempt to identify the causes of recent yield increases in the LTCCE after a period of decline and examine how these factors relate to the previous hypotheses about causes of yield decline. This analysis is made difficult by the simultaneous implementation of several changes. We will focus on the following questions:

1. How much did climatic factors contribute to the increased yields obtained after 1991?

2. How much of the increase in rice yields can be attributed to the increase in the fertilizer $\mathrm{N}$ rates and changes in timing of fertilizer $\mathrm{N}$ applications?

3. Did unusual fallow periods between rice crops contribute significantly to the yield increase observed after 1991 ?

\section{MATERIALS AND METHODS}

\section{Management of the LTCCE and Measurements during 1963 to 1991}

The LTCCE was established in 1963 at IRRI, Los Baños, Philippines $\left(14^{\circ} 11^{\prime} \mathrm{N}, 121^{\circ} 15^{\prime} \mathrm{E}, 21 \mathrm{~m}\right.$ elevation), on an Aquandic Epiaquoll (Soil Survey Staff, 1994) with amorphous materials and smectites as dominant clay minerals. In previous publications, the soil was classified as an Andaqueptic Haplaquoll because older versions of the Soil Taxonomy were used. Only key points will be given here, because a detailed description of the experiment is provided elsewhere (Cassman et al., 1995).

Abbreviations: $\mathrm{AE}_{\mathrm{N}}$, agronomic efficiency of applied fertilizer $\mathrm{N}$ DAT, days after transplanting; DS, dry season (January-April); EWS, early wet season (May-August); $\mathrm{IE}_{\mathrm{N}}$, internal efficiency of N; INS, indigenous N supply; LTCCE, long-term continuous cropping experiment; LWS, late wet season (September-December); $\mathrm{PE}_{\mathrm{N}}$, physiological efficiency of applied N; PI, panicle initiation; $\mathrm{RE}_{\mathrm{N}}$, recovery efficiency of applied N; WS, wet season. 
Table 1. Changes in rice crop management in the long-term continuous cropping experiment at Los Baños, Philippines.

\begin{tabular}{|c|c|c|c|}
\hline Year & $\mathbf{N}$ rate $\left(\mathrm{kg} \mathrm{ha}^{-1}\right) \dagger$ & $\mathbf{N}$ management $\ddagger$ & Other measuresII \\
\hline $1968 \S$ & $\begin{array}{l}\text { DS: } 120,60,40,0 \\
\text { WS: } 80,60,40,0\end{array}$ & $\begin{array}{r}120 \\
80\end{array}$ & Water buffalo (carabao) used for plowing and harrowing. \\
\hline 1969-1975 & DS: $150,100,50,0$ & $\begin{array}{r}125 \\
80+25\end{array}$ & Highest $N$ rate in 1969 DS was $140 \mathrm{~kg} \mathrm{~N} \mathrm{ha}^{-1}$. \\
\hline 1976-1979 & $\begin{array}{l}\text { DS: } 150,100,50,0 \\
\text { WS: } 90,60,30,0\end{array}$ & $\begin{array}{r}125+25 \\
60+30\end{array}$ & \\
\hline 1980-1990 & $\begin{array}{l}\text { DS: } 150,100,50,0 \\
\text { WS: } 90,60,30,0\end{array}$ & $\begin{array}{r}100+\mathbf{5 0} \\
\mathbf{6 0}+\mathbf{3 0}\end{array}$ & Mechanized soil tillage since 1986 (landmaster and hydrotiller). \\
\hline 1991 & $\begin{array}{l}\text { DS: } 150,100,50,0 \\
\text { WS: } 90,60,30,0\end{array}$ & $\begin{array}{r}100+50 \\
60+30\end{array}$ & $\begin{array}{l}\text { Removal of IR8. Only two crops grown (DS, Feb.-May and EWS, } \\
\text { July-Oct.). After harvest of the DS crop, the field dried } \\
\text { partially and remained fallow from May to July } 1991 \text {. Field } \\
\text { was fallow-flooded (Oct.-Dec.) until the } 1992 \text { DS crop. }\end{array}$ \\
\hline 1992 & $\begin{array}{l}\text { DS: } 189,126,63,0 \\
\text { WS: } 120,80,40,0\end{array}$ & $\begin{array}{l}54+36+60+39 \\
45+45+30\end{array}$ & $\begin{array}{l}\text { Prophylactic fungicide application ( } 2 \text { sprays) to prevent sheath } \\
\text { blight (Rhizoctonia solani). }\end{array}$ \\
\hline 1993 & $\begin{array}{l}\text { DS: } 216,144,72,0 \\
\text { WS: } 108,72,36,0\end{array}$ & $\begin{array}{l}\mathbf{6 0}+\mathbf{6 0}+\mathbf{6 0}+\mathbf{3 6} \\
\mathbf{5 4}+\mathbf{5 4}\end{array}$ & $\begin{array}{l}\text { Only two crops grown (DS, Jan.-Apr. and EWS, July-Oct.). } \\
\text { After harvest of the DS crop, the field dried and remained } \\
\text { fallow from May to July 1993. Field was fallow-flooded (Oct.- } \\
\text { Dec.) until planting of the } 1994 \text { DS crop. DS: N applied at } \\
\text { flowering when SPAD was below } 35 \text {. Furadan }(1 \times) \text { and } \\
\text { fungicide applied }(2 \times) \text {. }\end{array}$ \\
\hline 1994 & $\begin{array}{l}\text { DS: } 216,144,72,0 \\
\text { WS: } 117,78,39,0\end{array}$ & $\begin{array}{l}60+60+60+36 \\
36+36+45\end{array}$ & $\begin{array}{l}\text { Only two crops grown (DS, Jan.-Apr. and EWS, July-Oct.). } \\
\text { After harvest of the DS crop, the field dried partially and } \\
\text { remained fallow from May to July } 1994 \text {. Field was fallow- } \\
\text { flooded (Oct.-Dec.) until planting of the } 1995 \text { DS crop. DS: } \\
\text { N applied at flowering when SPAD was below } 36.5 \text {. EWS: N } \\
\text { applied after } 20 \text { DAT when SPAD reading was below 36. } \\
\text { Furadan }(1 \times) \text { and fungicide applied }(2 \times) \text {. }\end{array}$ \\
\hline 1995 & $\begin{array}{l}\text { DS: } 195,130,65,0 \\
\text { WS: } 110,73,36,0\end{array}$ & $\begin{array}{l}\mathbf{6 0}+\mathbf{6 0}+\mathbf{4 5}+\mathbf{3 0} \\
\mathbf{4 0}+\mathbf{4 0}+\mathbf{3 0}\end{array}$ & $\begin{array}{l}\text { Standard } N \text { split applications at critical growth stages, not SPAD- } \\
\text { based. Furadan }(1 \times) \text { and fungicide applied }(2 \times) \text {. }\end{array}$ \\
\hline
\end{tabular}

$\dagger \mathbf{N}$ rates for all four $\mathbf{N}$ levels are shown. DS, dry season; WS, wet season.

$\$ N$ splitting of the highest $N$ treatment in the DS and WS is shown. From 1969 to $1991, \mathbf{N}$ was applied in two splits: basal and 5 to 7 d before panicle initiation (PI). From 1992 to 1994, N was applied in two to four splits at basal, midtillering, PI, and flowering. In 1995, N was applied in four splits at midtillering, late tillering, PI, and flowering.

$\S$ Start of the experiment with its present basic design (rice-rice-rice, $\mathbf{N}$ rates $\times$ varieties).

II DAT, days after transplanting; EWS, early wet season. SPAD is the chlorophyll meter reading (dimensionless, SPAD 502 chlorophyll meter, Minolta, Ramsey, NJ).

Since January 1963, the 1-ha field used for the present LTCCE has been under continuous rice cultivation. From 1963 to 1968, 13 rice crops were grown in the same field at an average cropping intensity of 2.5 crops per year (IRRI, 1967). We only report data for the period after 1968 , because varieties grown from 1963 to 1968 had variable yield potential, and cropping practices varied. Variety 'IR8' was grown in each crop cycle starting with the 1966 DS. Other varieties were changed regularly to include the highest-yielding, most disease- and insect-resistant germplasm available at each point in time, but all varieties or breeding lines grown from 1968 to 1991 were high-yielding, semidwarf indica varieties with a similar harvest index and yield potential.

From 1968 to 1991, the experiment was conducted in a splitsplit-plot randomized complete block design with $\mathrm{N}$ rates as main plots, six varieties or elite breeding lines as subplots, and broadcast sowing or transplanting as crop establishment methods (sub-subplots). Nitrogen main plots ( 25 by $25 \mathrm{~m}$ ) were surrounded by permanent bunds to minimize soil, fertilizer, and floodwater movement. Three rice crops were grown each year (dry season, January-April; early wet season, MayAugust; late wet season, September-December). In each crop cycle, the soil remains water-saturated during the first 14 days after transplanting (DAT). Thereafter, a floodwater depth of 5 to $10 \mathrm{~cm}$ is maintained until the field is drained prior to harvest. Reflooding of the field for land preparation starts shortly after harvest, so that to our knowledge, during 1968 to 1991 the soil rarely dried.

Rates and application schemes of fertilizer nutrients in the LTCCE were initially selected to achieve maximum yield based on results of field experiments conducted in the 1960s (Cassman et al., 1995). Nitrogen rates were $0\left(\mathrm{~N}_{0}\right), 50\left(\mathrm{~N}_{1}\right)$, $100\left(\mathrm{~N}_{2}\right)$, and $150\left(\mathrm{~N}_{3}\right) \mathrm{kg} \mathrm{N}^{-1}$ in the DS and $0,30,60$, and $90 \mathrm{~kg} \mathrm{~N} \mathrm{ha}^{-1}$ in the wet season (WS), except in the $1968 \mathrm{DS}$ and the WS crops grown from 1968 to 1974 (Table 1). Typi- cally, two-thirds of the total amount of fertilizer $\mathrm{N}$ was incorporated into the soil at transplanting and one-third applied topdressed at 5 to $7 \mathrm{~d}$ before the panicle initiation (PI) stage. The $\mathrm{N}$ topdressing before PI was applied on the same day to all varieties in the experiment based on the development stage of one standard variety. In most years, all treatments received $26 \mathrm{~kg} \mathrm{P} \mathrm{ha}^{-1}$ for each rice crop, while $\mathrm{K}$ applications of $50 \mathrm{~kg}$ $\mathrm{K} \mathrm{ha}^{-1}$ crop $^{-1}$ began in 1980.

Plant measurements and crop records taken from 1968 to 1990 included grain yield, planting and harvest dates, fertilizers and pesticides applied, and general field observations on insect and disease severity for each crop. Grain yields were measured in 5- or $10-\mathrm{m}^{2}$ harvest areas within each plot at maturity. All plants were cut at soil surface level, and all straw was completely removed from the field. Only limited soil analyses were performed, and soil and plant samples were not archived until after 1983.

\section{Management of the LTCCE and Measurements during 1991 to 1995}

Beginning with the 1991 EWS crop and continuing until 1995, various changes in the design of the experiment and crop management practices occurred (Table 1). Although some of these changes were caused by the need to renovate irrigation infrastructure at the site or unavoidable technical constraints, a number of changes were implemented to reverse the yield decline observed from 1968 to 1991 and to improve the quality of field management and measurements.

Because statistical differences between yields of directseeded and transplanted treatments were small, the directseeded subplot treatment was eliminated in the $1991 \mathrm{WS}$, and all rice was transplanted thereafter. The current experimental design is therefore a split-split-plot randomized complete block with $\mathrm{N}$ rate as main plots and three varieties as subplots 


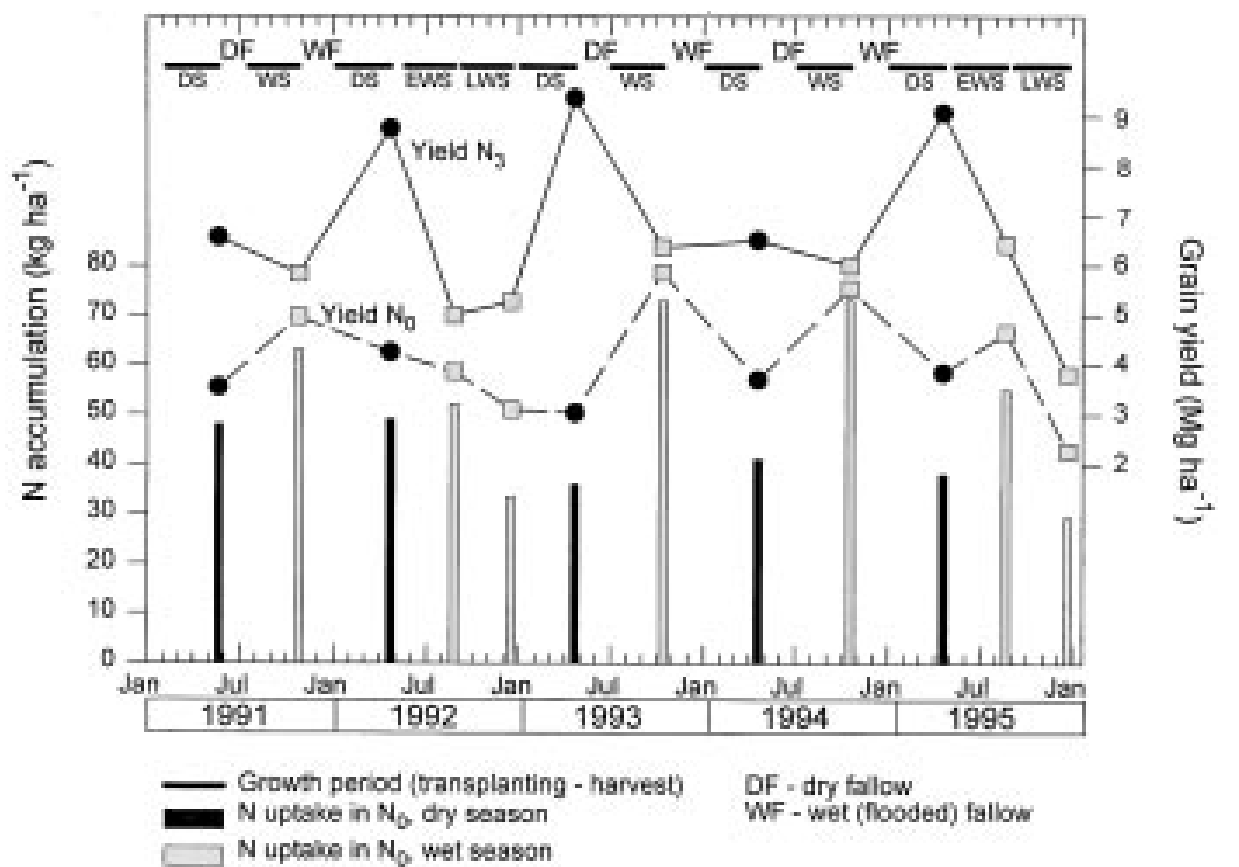

Fig. 1. Cropping calendar and the influence of fallow periods on total $\mathbf{N}$ accumulation at maturity and grain yield of rice in the control $\left(\mathbf{N}_{0}\right.$, dashed line) and high-N treatments $\left(\mathrm{N}_{3}\right.$, solid line) of the long-term continuous cropping experiment at Los Baños, Philippines. Values are treatment averages of IR72 from 1991 to 1995.

and sub-subplots. From 1991 to 1995 , IR72 was grown as the standard reference variety together with two elite breeding lines (IR59682-132-1-1-2 and IR60819-50-3-3). These varieties had similar yield potential to those grown before 1991, but have greater yield stability due to improved resistance to major pests. Selected varieties represented the best available genotypes, but only varieties with a similar maturity were used. Mean days to maturity for the varieties used from 1970 to 1972 was $124 \mathrm{~d}( \pm 4 \mathrm{SD})$, as compared with $115 \mathrm{~d}( \pm 1 \mathrm{SD})$ in 1992-1993. More uniform maturity and elimination of broadcast-seeded subplots facilitated greater precision in water management and timing of $\mathrm{N}$ applications in relation to the stage of crop development (Cassman et al., 1995).

Nitrogen rates were increased in 1991-1992, the number of split applications was changed from two to three or four, and the timing of $\mathrm{N}$ applications was modified (Table 1). In general, a more even spread of $\mathrm{N}$ addition was implemented, including a late N dose at flowering in the DS crop. In 1993 and 1994, chlorophyll meter (SPAD 502, Minolta, Ramsey, $\mathrm{NJ}$ ) readings of the uppermost fully expanded leaf (Y-leaf) were used to determine the timing of $\mathrm{N}$ topdressings based on thresholds established by Peng et al. (1996). In the 1994 and $1995 \mathrm{DS}, \mathrm{ZnSO}_{4}$ was applied as a blanket application to all plots to provide $10 \mathrm{~kg} \mathrm{Zn} \mathrm{ha}{ }^{-1}$.

In years with the normal triple-crop system, soil does not have time to dry in the 15 - to 20 -d fallow period between harvest and transplanting (Fig. 1). However, only two rice crops were grown in 1991, 1993, and 1994 because the deep tube well and irrigation conveyance system were reconstructed during an extended fallow period after the DS crop in 1991 and 1993. In 1994, not enough seed of two new lines was available to produce two WS crops. Therefore, in years with double cropping, only one WS crop was transplanted in July and harvested in October. Surface soil dried thoroughly during the extended fallow of $70 \mathrm{~d}$ between the $1993 \mathrm{DS}$ and WS crops, and there was partial drying during this period in 1991 and 1994. After harvest of the single WS crop in those years, the soil remained flooded from October to December until puddling operation of the next DS crop (Cassman et al., 1996).

Beginning in 1992, prophylactic applications of benlate (methyl- $N$-(1-butylcarbamoyl)-2-benzimidazole carbamate, known as benomyl) were done at 4 to $6 \mathrm{~d}$ after panicle initiation and before flowering to control sheath blight (Rhizoctonia solani). Likewise, a prophylactic application of furadan $(2,3$ dihydro-2,2-dimethylbenzofuran-7-y, known as carbofuran) at heading stage was introduced in the 1993 DS crop to avoid stemborer (Scirpophaga spp., Chilo spp. ) damage. Weed management has remained the same, with primary control from herbicides and handweeding as needed.

Beginning with the 1991 DS, a more detailed sampling procedure was implemented. Dates of occurrence of important growth stages, complete pesticide application profiles, and soil moisture status between crops were recorded. Plant $\mathrm{N}$ accumulation was measured for each crop. Grain yields were obtained from a central $5-\mathrm{m}^{2}$ harvest area at harvestable maturity. A 12-hill plant sample was collected at physiological maturity, when 90 to $95 \%$ of all grains had lost their green color. This sample was used to determine nutrient concentrations in plant tissue. Grain and straw subsamples from the 12-hill sample were dried to constant weight at $70^{\circ} \mathrm{C}$. Straw yields were estimated from the oven-dry grain yield of the $5-\mathrm{m}^{2}$ harvest area and the grain-to-straw ratio of the 12-hill sample. All yields $\left(\mathrm{Mg} \mathrm{ha}^{-1}\right)$ are reported at a standard moisture content of $140 \mathrm{~g} \mathrm{H}_{2} \mathrm{O} \mathrm{kg}{ }^{-1}$ fresh weight. Nitrogen concentrations in grain and straw were measured by micro-Kjeldahl digestion, distillation, and titration (Bremner and Mulvaney, 1982).

\section{Crop Modeling and Statistical Analysis}

The crop simulation models ORYZA1 (Kropff et al., 1993) and WOFOST 7.1 (van Diepen et al., 1989; Boogaard et al., 1998) were used to estimate potential yields of IR72 for all rice crops grown from 1968 to 1995 using the actual weather data collected daily. The term potential yield is defined as the maximum attainable yield of a variety, restricted only by the season-specific climatic conditions and assuming optimal $\mathrm{N}$ and water supply. Dry season potential yields predicted by WOFOST 7.1 tended to be 0.5 to $1.0 \mathrm{Mg}$ ha $^{-1}$ lower than those estimated by ORYZA1, whereas the early wet season yields were not significantly different between the two models. 


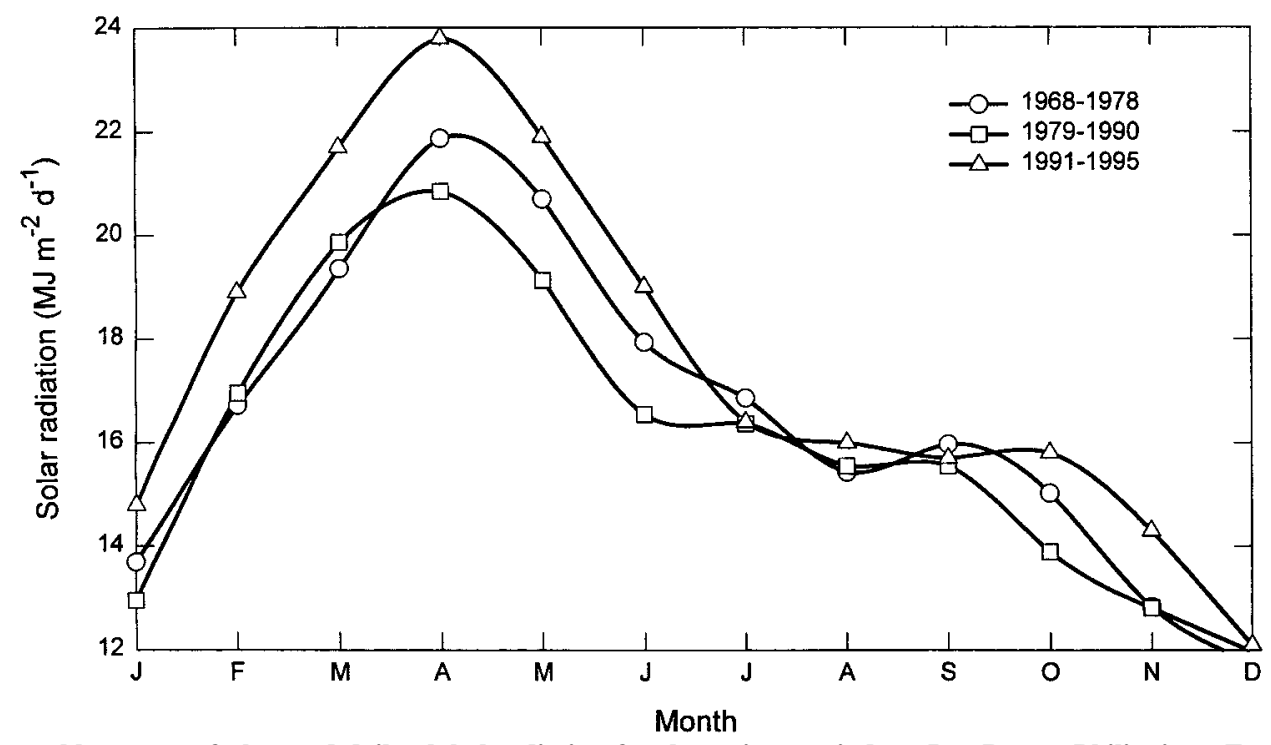

Fig. 2. Long-term monthly means of observed daily global radiation for three time periods at Los Baños, Philippines. For each period, values shown are the average of the mean monthly radiation measured in each year included. The curve for 1991 to 1995 only includes solar radiation after changes in crop management were implemented.

Both models predicted similar total aboveground dry matter yields, but differed in their treatment of dry matter partitioning. Values of potential yields cited in this paper are averages predicted by the two crop models. The attainable Nlimited yield, simulated by WOFOST 7.1, was defined as the potentially attainable yield based on the actual measured $\mathrm{N}$ accumulation and climatic conditions with no other constraints to growth.

The total $\mathrm{N}$ accumulation in grain and straw from plots that did not receive $\mathrm{N}$ fertilizer $\left(\mathrm{N}_{0}\right)$ was considered to provide an estimate of the indigenous $\mathrm{N}$ supply (INS), which includes supply of $\mathrm{N}$ from soil pools as well as other indigenous sources such as biological $\mathrm{N}_{2}$ fixation, rainfall, and irrigation. Nitrogen use efficiencies were estimated using the differences between $\mathrm{N}$-fertilized treatments and the unfertilized control, as defined by Cassman et al. (1998). Terms used are $\mathrm{AE}_{\mathrm{N}}$, agronomic efficiency of applied $\mathrm{N}$ ( $\mathrm{kg}$ grain yield increase per $\mathrm{kg} \mathrm{N}$ applied); $\mathrm{RE}_{\mathrm{N}}$, apparent recovery efficiency of applied $\mathrm{N}(\mathrm{kg}$ $\mathrm{N}$ taken up per $\mathrm{kg} \mathrm{N}$ applied); $\mathrm{PE}_{\mathrm{N}}$, physiological efficiency of applied $\mathrm{N}$ ( $\mathrm{kg}$ grain yield increase per $\mathrm{kg}$ fertilizer $\mathrm{N}$ taken up); and $\mathrm{IE}_{\mathrm{N}}$, internal $\mathrm{N}$ efficiency ( $\mathrm{kg}$ grain per $\mathrm{kg} \mathrm{N}$ taken up).

Long-term yield trends were plotted for the highest-yielding variety in each year because no single variety was grown throughout the whole experimental period. The averages of all three varieties were not used because before 1991, one variety (IR8) became increasingly affected by tungro. Note, however, that potential yield and $\mathrm{N}$ uptake data shown for the period from 1991 to 1995 are for cv. IR72 only because the crop models used were not calibrated for other varieties grown. Linear regression of yields (in logarithmic form) against a time trend variable was performed for the period 1968 to 1991 :

$$
\ln (Y)=a+b t
$$

where $Y$ is the grain yield $\left(\mathrm{kg} \mathrm{ha}^{-1}\right), a$ is a constant, $t$ is the time after start of the experiment (year number) and $b$ is the slope or magnitude of the yield trend (\%/100). A logarithmic form was chosen in order to display yield trends in different treatments in relative form; i.e., a magnitude of -0.01 represents an average yield decline at the rate of $-1 \%$ per year. Wet and dry season data were analyzed separately.

Quadratic N response models of the form

$$
Y=\mathrm{YN}_{0}+b \mathrm{FN}-c \mathrm{FN}^{2}
$$

where $\mathrm{FN}$ is the amount of $\mathrm{N}$ fertilizer applied $\left(\mathrm{kg} \mathrm{ha}^{-1}\right)$, were fitted to the relationship between grain yield and amount of $\mathrm{N}$ applied during different time periods (1968-1972, 1978-1982, 1986-1990, and 1992-1995). Data from the 1994 DS crop were excluded from the average $\mathrm{N}$ response function because of severe typhoon damage. Response functions for early wet season crops from 1991 to 1995 were separated into years with a dry fallow period before planting of the early wet season crop (1991, 1993, and 1994) and years with no fallow period (1992 and 1995). A single-factor analysis of variance was used to test for significant differences in grain yields and $\mathrm{N}$ accumulation among $\mathrm{N}$ treatments (main plots).

\section{RESULTS AND DISCUSSION Climatic Yield Potential and Yield Gaps}

Despite fluctuations between cropping seasons and years, no significant trend in solar radiation and the climatic yield potential was observed from 1968 to 1991 (Fig. 2 and 3). Incident solar radiation was highest in April, with 21 to $24 \mathrm{MJ} \mathrm{m}^{-2} \mathrm{~d}^{-1}$ (end of the DS crop), and lowest in December (Fig. 2). With the onset of tropical monsoons in July, radiation decreased to $16 \mathrm{MJ}$ $\mathrm{m}^{-2} \mathrm{~d}^{-1}$ and remained at that level until November. During this period, the early and late wet season crops were grown. The average solar radiation measured from 1991 to 1995 was greater than that in the 1980 s throughout most of the year (Fig. 2).

Simulated potential DS yields show no clear trends from 1968 to 1991, but an increase thereafter (Fig. 3). Depending on seasonal variations in planting dates and climate, the simulated potential yields from the 1991 EWS to 1995 ranged from 9.1 to $10.0 \mathrm{Mg} \mathrm{ha}^{-1}$ in the DS and 5.9 to $7.0 \mathrm{Mg} \mathrm{ha}^{-1}$ in the EWS (Fig. 3, Table 2). This compares with 8.1 to $8.7 \mathrm{Mg} \mathrm{ha}^{-1}$ in the DS and 5.7 to $5.8 \mathrm{Mg} \mathrm{ha}^{-1}$ in the EWS between 1989 and the 1991 DS. The smaller simulated yield potential for 


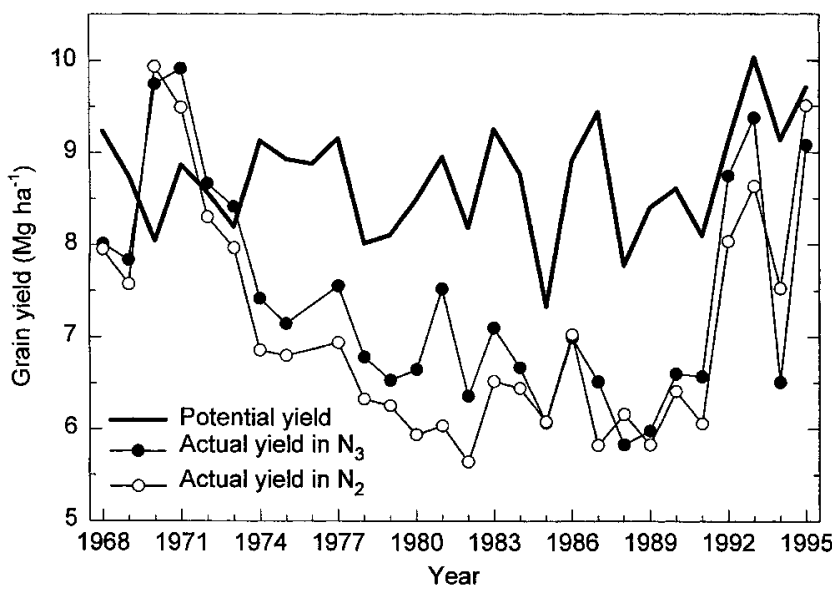

Fig. 3. Simulated potential dry season rice yield of IR72 and actual yields of the highest-yielding variety in each year at Los Baños, Philippines. Simulated potential yields are means of potential yields predicted by ORYZA1 and WOFOST 7.1.

the $1991 \mathrm{DS}\left(8.1 \mathrm{Mg} \mathrm{ha}^{-1}\right)$ was due to late planting. This crop was planted on 9 Feb. 1991, one month later than usual, so that flowering occurred in the hottest period of the year.

Yield trends and yield gap analysis suggest that yield losses were small after changes in crop management were implemented starting with the 1991 WS crop. During 1985 to 1991, the late period of the yield decline, actual yields achieved in the highest $\mathrm{N}$ treatment $\left(\mathrm{N}_{3}\right)$ were only 60 to $70 \%$ of the potential yield (Fig. 3).
During 1992 to 1995 , actual DS yields in the $\mathrm{N}_{3}$ treatment ranged from 85 to $94 \%$ of the potential yield (Fig. 3 , Table 2), or from 90 to $102 \%$ of the simulated $\mathrm{N}$ limited yield (data not shown). The only exception was the 1994 DS, when yields were low due to lodging caused by a typhoon in early April 1994 (Fig. 3). In WS or EWS crops grown from 1991 to 1995 , actual yields in $\mathrm{N}_{3}$ were 79 to $101 \%$ of the potential yield, or 87 to $98 \%$ of the simulated N-limited yield.

\section{Grain Yield and Nitrogen Uptake during 1991 to 1995}

The yield decline observed until the 1991 DS was reversed in both DS and WS crops. Beginning with the 1991 EWS crop grown after the first dry fallow period, grain yields in all treatments that received $\mathrm{N}$ fertilizer increased to levels similar to those measured during the initial years of the experiment (Fig. 3 and 4). A maximum grain yield of $9.4 \mathrm{Mg} \mathrm{ha}^{-1}$ was measured in the 1993 DS (variety IR59682-132-1-1-2), as compared with 9.7 $\mathrm{Mg} \mathrm{ha}{ }^{-1}$ in the 1970 DS (IR661-1-140-3-2) or 9.9 $\mathrm{Mg} \mathrm{ha}^{-1}$ in the $1971 \mathrm{DS}$ (IR24). Note that the high yield in 1993 was achieved with a 115-d variety, whereas those grown in 1970-1971 required $127 \mathrm{~d}$ from sowing to maturity. Dry season yields in both the $\mathrm{N}_{2}$ and the $\mathrm{N}_{3}$ treatments increased similarly (Fig. 3). Early WS yields increased to levels of about $6 \mathrm{Mg}^{-1}$. Three crops grown per year after 1991 had a total average annual grain production of $19 \mathrm{Mg} \mathrm{ha}^{-1} \mathrm{yr}^{-1}$ in the $\mathrm{N}_{2}$ and $\mathrm{N}_{3}$ treat-

Table 2. Simulated potential yield, measured grain yields, and $\mathbf{N}$ use efficiencies of rice (cv. IR72) in dry seasons (DS) and early wet seasons (EWS) of the long-term continuous cropping experiment at Los Baños, Philippines, from 1991 EWS to 1995 EWS.

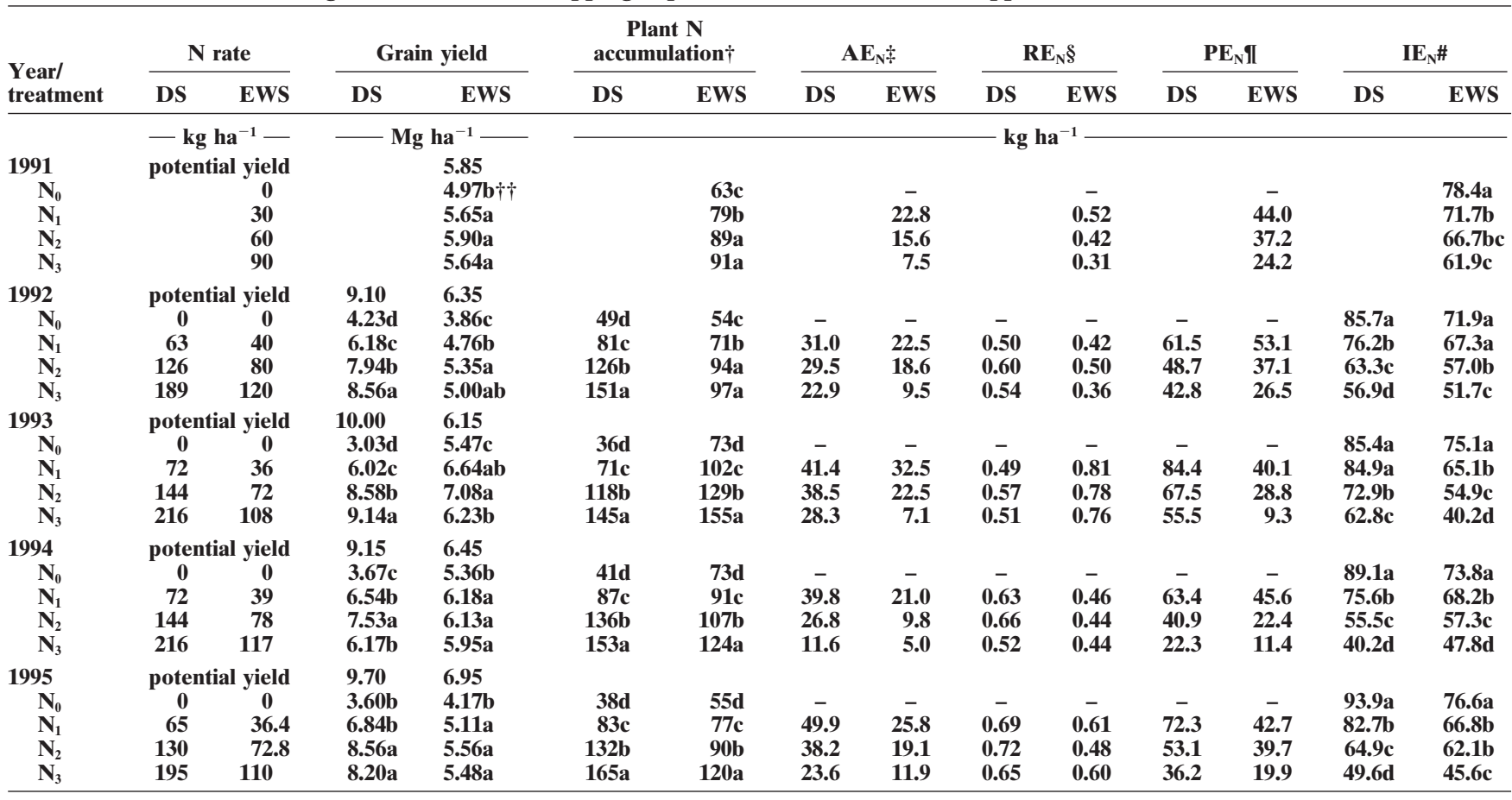

$\dagger$ Total plant $\mathbf{N}$ accumulation with grain and straw.

+ Agronomic efficiency of applied $\mathbf{N}$ (kg grain yield increase per $\mathbf{k g ~} \mathbf{N}$ applied).

$\S$ Apparent recovery efficiency of applied $\mathrm{N}$ ( $\mathrm{kg} \mathrm{N}$ taken up per $\mathrm{kg} \mathrm{N}$ applied).

II Physiological efficiency of applied $\mathbf{N}$ (kg grain yield increase per $\mathbf{k g}$ fertilizer $\mathbf{N}$ taken up).

\# Internal efficiency of $\mathbf{N}$ taken up by the plant (kg grain per $\mathbf{k g} \mathbf{N}$ taken up).

$t \dagger$ Within each year and season, means followed by the same letter are not significantly different according to LSD (0.05). 

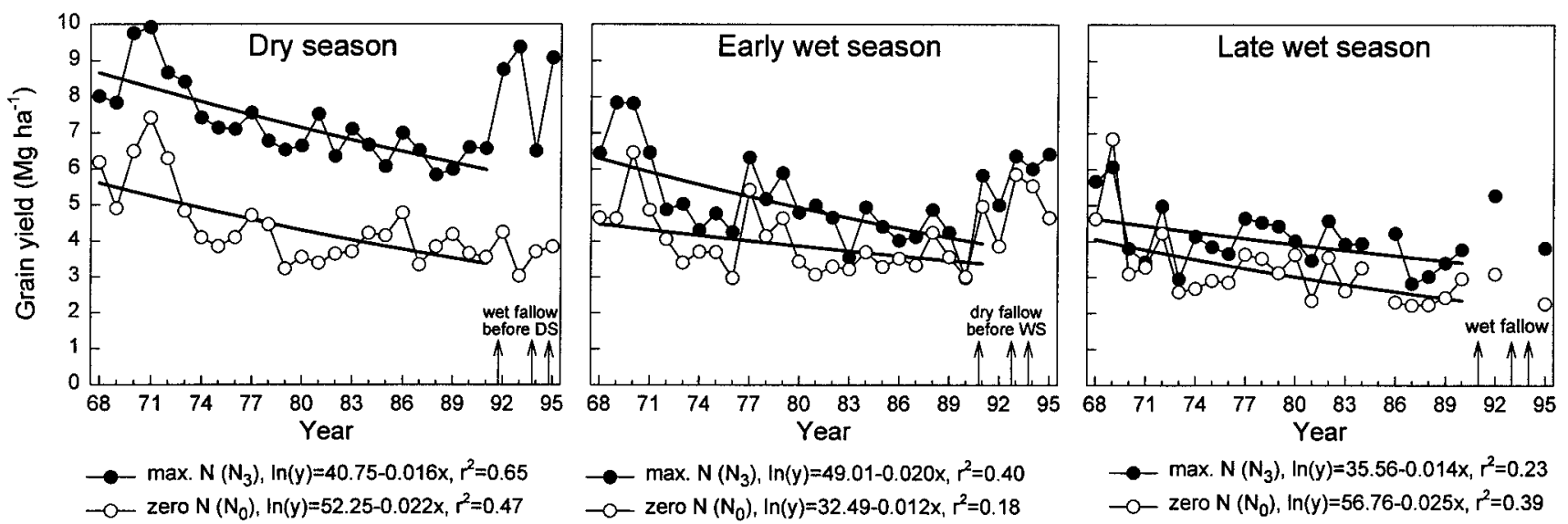

Fig. 4. Rice yield trends in the triple-crop system of the long-term continuous cropping experiment at Los Baños, Philippines. Data points and trends shown refer to the grain yield of the highest-yielding variety in each year for each crop cycle at the highest $\mathrm{N}_{\text {level }}\left(\mathrm{N}_{3}\right.$, closed circles) and the control ( $\mathbf{N}_{0}$, open circles). In 1991, 1993, and 1994, only two rice crops were grown (dry season, January-April; wet season, July-October). Fallow periods are indicated with arrows. The slope of the regression lines represents the average yield decline per year (\%/100).

ments, which was close to the annual production from 1968 to 1972 (Table 3). Growing two rice crops per year restored the annual grain production only up to levels achieved with triple cropping about $15 \mathrm{yr}$ ago (14 Mg $\mathrm{ha}^{-1} \mathrm{yr}^{-1}$ ). The yield reversal on an annual basis only occurred in treatments with $\mathrm{N}$ applied (Table 3 ).

Nitrogen accumulation in the aboveground biomass at maturity increased with increasing $\mathrm{N}$ rate (Table 2). Between 1992 to 1995, average N accumulation of IR72 in the DS was $154 \mathrm{~kg} \mathrm{~N} \mathrm{ha}^{-1}$ in $\mathrm{N}_{3}$ (average $\mathrm{N}$ rate $=$ $204 \mathrm{~kg} \mathrm{~N} \mathrm{ha}^{-1}$ ) and $128 \mathrm{~kg} \mathrm{~N} \mathrm{ha}^{-1}$ in $\mathrm{N}_{2}$ (average $\mathrm{N}$ rate $\left.=136 \mathrm{~kg} \mathrm{~N} \mathrm{ha}^{-1}\right)$. This is compared with only 105 $\mathrm{kg} \mathrm{N}$ ha ${ }^{-1}$ in the 1991 DS crop $\left(\mathrm{N}_{3}, \mathrm{~N}\right.$ rate $=150 \mathrm{~kg} \mathrm{~N}$ $\mathrm{ha}^{-1}$ ), the last crop grown before changes in $\mathrm{N}$ management were implemented (Table 4). We do not have more data on plant $\mathrm{N}$ accumulation before 1991 to prove that plant $\mathrm{N}$ uptake after the 1991 DS was significantly larger than during the period of the yield decline. However, a concomitant long-term decrease in grain protein content observed at the IRRI research farm is consistent with the observed decrease in plant $\mathrm{N}$ accumulation in the LTCCE. For example, in the experimental block adjacent to the LTCCE, grain protein in unfertilized plots was about $7 \%$ in the 1960 s and 1970 s, but only 5 to $5.5 \%$ in the 1991 WS (Perez et al., 1996).

Dry season grain yields in the $\mathrm{N}_{0}$ treatment did not increase and remained close to the negative trend line fitted for the 1968 to 1991 period, suggesting an average yield decline of $2.2 \%$ per year (Fig. 1 and 4 ). However, the unusual dry fallow periods after the harvest of DS rice (May-July 1991, 1993, and 1994) significantly increased the grain yield of the WS rice grown in the following crop cycle, largely due to an increase in the
INS. Wet season yields of the highest-yielding variety in the $\mathrm{N}_{0}$ were 4.9 to $5.7 \mathrm{Mg} \mathrm{ha}^{-1}$ in years following a dry fallow period (1991, 1993, and 1994), which were considerably higher than yields of 3.6 to $4.7 \mathrm{Mg} \mathrm{ha}^{-1}$ in years with the normal triple-crop schedule in 1992 and 1995 and 3.0 to $3.7 \mathrm{Mg} \mathrm{ha}^{-1}$ in the 1980s (Fig. 4). Total $\mathrm{N}$ accumulation of IR72 in $\mathrm{N}_{0}$ plots ranged from 63 to $73 \mathrm{~kg} \mathrm{ha}^{-1}$ in the WS crops following a dry fallow period (1991, 1993, and 1994), but was only 54 to $55 \mathrm{~kg} \mathrm{ha}^{-1}$ in the normal triple-crop years of 1992 and 1995 (Table 2, Fig. 1). Assuming an average internal efficiency of $75 \mathrm{~kg}$ grain $\mathrm{kg}^{-1}$ plant $\mathrm{N}$ accumulation, this average increase in INS of $15 \mathrm{~kg} \mathrm{ha}^{-1}$ is equivalent to a grain yield increase of about $1.1 \mathrm{Mg} \mathrm{ha}^{-1}$ and explains almost all of the actual yield difference of $1.3 \mathrm{Mg} \mathrm{ha}^{-1}$ observed in the $\mathrm{N}_{0}$ plots (average yield of $5.3 \mathrm{Mg} \mathrm{ha}^{-1}$ after fallow vs. 4.0 $\mathrm{Mg} \mathrm{ha}^{-1}$ without a fallow).

In contrast to the large effect of a dry fallow period on the INS of the subsequent WS crop, there was no detectable residual effect on the INS in the DS crop grown in the following year. Dry season grain yields in $\mathrm{N}_{0}$ were generally similar to those in the DS of years with the normal triple-crop system before 1991 (Fig. 1 and 4, Table 2). Average $\mathrm{N}$ accumulation in $\mathrm{N}_{0}$ plots was $42 \mathrm{~kg} \mathrm{~N}^{-1}$ in DS crops succeeding a triple-crop year (1991 and 1993 DS) and $43 \mathrm{~kg} \mathrm{~N} \mathrm{ha}^{-1}$ in DS crops succeeding a double-crop year (1992, 1994, and 1995 DS). In years with double cropping, prolonged flooded fallow periods occurred after the harvest of the WS rice crops (October-December 1991, 1993, and 1994), so that little soil aeration occurred before the DS crop was planted.

Using the analytical approach of Witt et al. (1999),

Table 3. Annual rice production $\left(\mathrm{Mg} \mathrm{ha}^{-1} \mathrm{yr}^{-1}\right)$ in the long-term continuous cropping experiment at Los Baños, Philippines. Values are based on the grain yield of the highest-yielding rice variety in each crop.

\begin{tabular}{|c|c|c|c|c|c|}
\hline Treatment & $1968-1972 \dagger$ & $1978-1982 \dagger$ & $1986-1990 \dagger$ & $1992,1995 \dagger$ & $1993,1994+$ \\
\hline $\mathbf{N}_{0}$ & 15.6 & 10.6 & 9.9 & 11.0 & 9.1 \\
\hline $\mathbf{N}_{1}$ & 18.2 & 13.1 & 12.2 & 16.1 & 13.2 \\
\hline $\mathbf{N}_{2}$ & 19.9 & 13.7 & 13.8 & 19.1 & 14.9 \\
\hline $\mathbf{N}_{3}$ & 20.3 & 16.1 & 13.9 & 19.2 & $14.1 \S$ \\
\hline
\end{tabular}

$\dagger$ Three rice crops grown (dry season, early wet season, and late wet season).

+ Two rice crops grown (dry season, and wet season).

$\S$ Low yield in $N_{3}$ in the 1994 dry season due to lodging (typhoon damage). 
Table 4. Grain yields and $N$ use efficiencies of rice (cv. IR72) in the 1991 dry season (DS) of the long-term continuous cropping experiment at Los Baños, Philippines. The 1991 DS crop was the last crop grown before changes in crop management were introduced.

\begin{tabular}{|c|c|c|c|c|c|c|c|}
\hline Treatment & $N$ rate & Grain yield & $\begin{array}{c}\text { Plant } \mathbf{N} \\
\text { accumulation }\end{array}$ & $\mathbf{A} \mathbf{E}_{\mathbf{N}}^{\dagger} \dagger$ & $\mathbf{R E}_{\mathrm{N}} \ddagger$ & $\mathbf{P E}_{\mathrm{N}} \S$ & $\mathbf{I E}_{\mathrm{N}}$ II \\
\hline & $\operatorname{kg~ha}^{-1}$ & Mg ha $^{-1}$ & $\mathrm{~kg} \mathrm{ha}^{-1}$ & 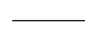 & 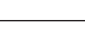 & 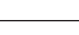 & \\
\hline $\mathbf{N}_{0}$ & 0 & 3.55d\# & $48 d$ & - & - & - & 73.9a \\
\hline $\mathbf{N}_{1}$ & $\mathbf{5 0}$ & $5.18 \mathrm{c}$ & $75 \mathrm{c}$ & 32.6 & 0.53 & 61.6 & $69.5 \mathrm{a}$ \\
\hline $\mathbf{N}_{2}$ & 100 & $6.06 \mathrm{~b}$ & $87 b$ & 25.1 & 0.39 & 65.2 & 70.0a \\
\hline $\mathbf{N}_{3}$ & 150 & $6.57 \mathrm{a}$ & $105 a$ & 20.1 & 0.38 & 52.8 & $62.4 b$ \\
\hline
\end{tabular}

$\dagger$ Agronomic efficiency of applied $\mathbf{N}$ (kg grain yield increase per $\mathrm{kg} \mathbf{N}$ applied).

$\$$ Apparent recovery efficiency of applied $\mathbf{N}$ (kg $\mathbf{N}$ taken up per $\mathrm{kg} \mathrm{N}$ applied).

$\S$ Physiological efficiency of applied N (kg grain yield increase per kg fertilizer $\mathbf{N}$ taken up).

II Internal efficiency of $\mathbf{N}$ taken up by the plant ( $\mathrm{kg}$ grain per $\mathrm{kg} \mathbf{N}$ taken up).

\# Within each column, means followed by the same letter are not significantly different according to LSD (0.05).

the relationship between grain yield and $\mathrm{N}$ accumulation indicates that $\mathrm{N}$ deficiency limited growth of plants in the $\mathrm{N}_{0}$ and $\mathrm{N}_{1}$ treatments, whereas plant $\mathrm{N}$ supply was not a major growth limitation in the $\mathrm{N}_{2}$ and $\mathrm{N}_{3}$ treatments after 1991 (Fig. 5). Dry season data points of $\mathrm{N}_{0}$ and $\mathrm{N}_{1}$ treatments fell close to the line of maximum dilution of $\mathrm{N}$ in the plant $\left(\mathrm{Y}_{\mathrm{ND}}\right.$, high $\left.\mathrm{IE}_{\mathrm{N}}\right)$, confirming that $\mathrm{N}$ was the major growth-limiting factor in these treatments. Most of the DS data points for the $\mathrm{N}_{2}$ and $\mathrm{N}_{3}$ treatments were close to the simulated optimal nutrition situation. In the WS, $\mathrm{N}$ was less diluted in the plant in $\mathrm{N}_{0}$ and $\mathrm{N}_{1}$ treatments than in the DS (lower $\mathrm{IE}_{\mathrm{N}}$ ), but most of the data points from the $\mathrm{N}_{2}$ and $\mathrm{N}_{3}$ treatments also were close to the line of optimal nutrition. The fact that many of the highest yields fell close to the line of optimal $\mathrm{IE}_{\mathrm{N}}$ is further evidence that there was no significant yield loss from pests or abiotic stresses. However, both in DS and WS, some data points fell close to the line of maximum accumulation of $\mathrm{N}$ in the plant $\left(\mathrm{Y}_{\mathrm{NA}}\right)$. These are situations in which unusual events decreased grain yield. They include lodging damage due to a typhoon $\left(\mathrm{N}_{3}\right.$ in the $\left.1994 \mathrm{DS}\right)$ or selected cases of increased disease incidence and severity at the highest $\mathrm{N}$ level $\left(\mathrm{N}_{3}\right.$ in the 1992 and $\left.1993 \mathrm{WS}\right)$.

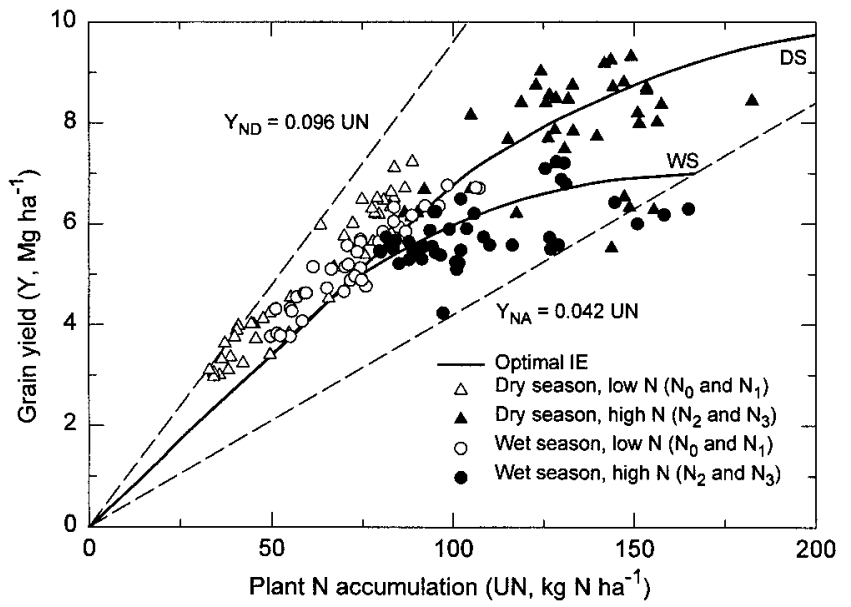

Fig. 5. Relationship between grain yield of IR72 and accumulation of $\mathbf{N}$ in total aboveground plant dry matter at maturity of rice crops harvested in the long-term continuous cropping experiment at Los Baños, Philippines, from 1991 to 1995. The dashed line on the left represents the boundary of maximum possible dilution $\left(Y_{\mathrm{ND}}\right)$, while the dashed line on the right indicates the boundary of maximum possible accumulation $\left(\mathbf{Y}_{\mathrm{NA}}\right)$ of $\mathrm{N}$ as defined by Witt et al. (1999). The solid lines show the simulated optimal internal $\mathrm{N}$ use efficiency (IE) for typical dry season (DS) and wet season (WS) crops with a potential yield of 10 and $7 \mathrm{Mg} \mathrm{ha}^{-1}$, respectively (Witt et al., 1999).

\section{Response to Fertilizer Nitrogen and Nitrogen Use Efficiencies}

Initially (1968-1972), yield response to N was very good in both DS and WS crops, resulting in high yields with moderate amounts of applied $\mathrm{N}$ fertilizer and high $\mathrm{N}$ use efficiencies (Fig. 6). After $10 \mathrm{yr}$ of triple rice cropping, the $\mathrm{N}$ response functions shifted downward. Initially, this was mainly a shift in the intercept $\left(\mathrm{YN}_{0}\right)$. At the end of the yield decline period (1986-1990), the average $\mathrm{N}$ response functions in the DS and EWS also indicated a decline in $\mathrm{AE}_{\mathrm{N}}$ (slope). After the $1991 \mathrm{DS}$, significant changes in the $\mathrm{N}$ response functions occurred, but they differed between DS and WS crops. In the DS,

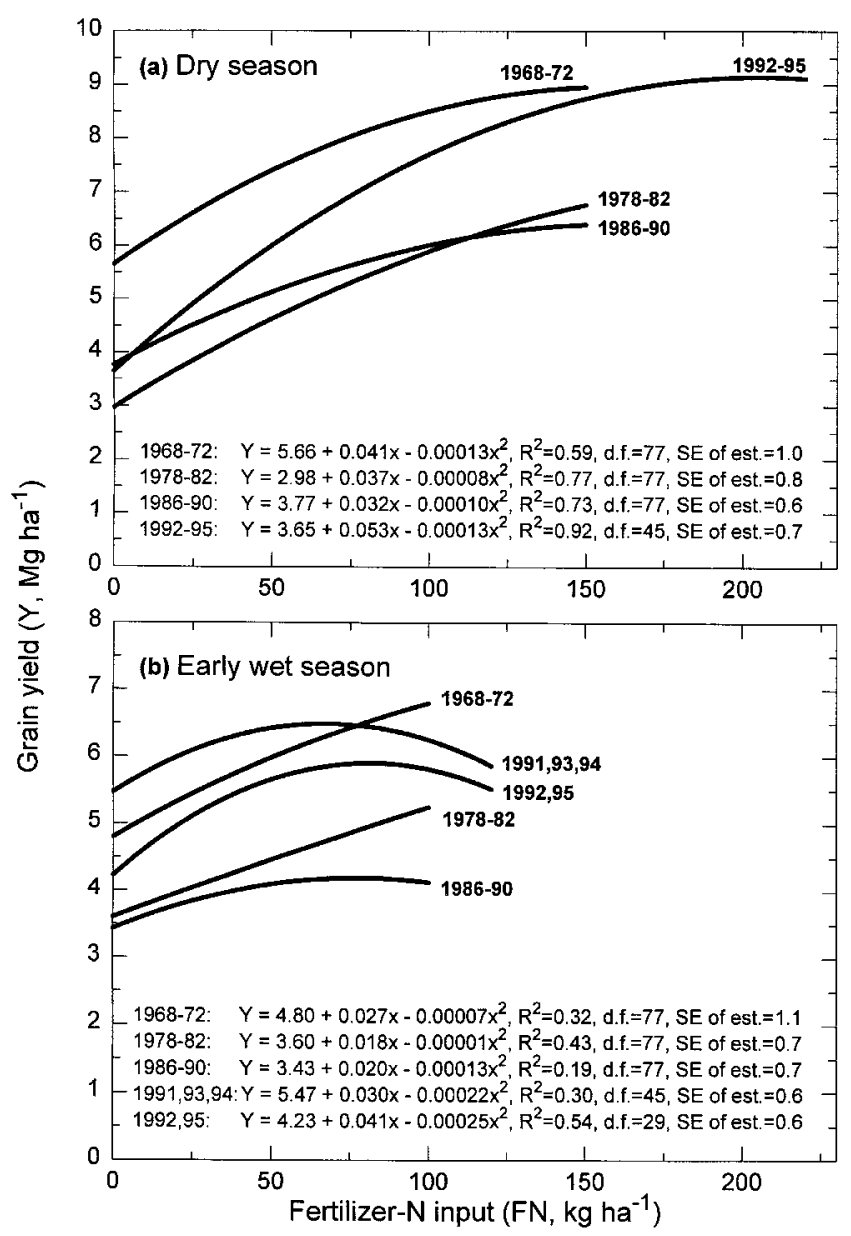

Fig. 6. Response of rice yields to fertilizer $\mathrm{N}$ rates during different periods of the long-term continuous cropping experiment at Los Baños, Philippines. Regressions are based on the highest-yielding variety in each season, with four replicate plots per $\mathbf{N}$ level. 
the response function fitted for 1992 to 1995 had the same intercept as in 1986 to 1990, but a greater slope. This shift indicates no change in the $\mathrm{YN}_{0}$, but a significant increase in $\mathrm{AE}_{\mathrm{N}}$. With the exception of the typhoondamaged crop in the $1994 \mathrm{DS}$, the average $\mathrm{AE}_{\mathrm{N}}$ from 1992 to 1995 was $35 \mathrm{~kg} \mathrm{~kg}^{-1}$ in $\mathrm{N}_{2}$ and $25 \mathrm{~kg} \mathrm{~kg}^{-1}$ in $\mathrm{N}_{3}$ plots. Increases in $\mathrm{AE}_{\mathrm{N}}$ were mainly due to an increase in $\mathrm{RE}_{\mathrm{N}}$, not due to a change in $\mathrm{PE}_{\mathrm{N}}$ (Tables 2 and 4). From 1992 to 1995 , the $\mathrm{RE}_{\mathrm{N}}$ was generally high in the DS $\left(\mathrm{N}_{2}, 0.57-0.72 \mathrm{~kg} \mathrm{~kg}^{-1} ; \mathrm{N}_{3}, 0.51-0.65 \mathrm{~kg} \mathrm{~kg}^{-1}\right.$; Table 2). For comparison, the $\mathrm{RE}_{\mathrm{N}}$ was only 0.38 to $0.39 \mathrm{~kg}$ $\mathrm{kg}^{-1}$ in the 1991 DS (Table 4).

Wet season $\mathrm{N}$ response functions were more erratic (Fig. 6; $R^{2}$ of $0.19-0.54$ in the WS compared with 0.59 0.92 for DS crops), and they differed between years with double cropping (1991, 1993, and 1994) and triple cropping (1992 and 1995). The former had a significantly larger intercept than the latter due to the effects of fallowing. In both cases, however, the response functions as well as the estimated $\mathrm{AE}_{\mathrm{N}}$ (Table 2) indicate that the amount of $\mathrm{N}$ applied in the $\mathrm{N}_{3}$ plots exceeded the requirement for maximum yields. Average $\mathrm{WS} \mathrm{AE}_{\mathrm{N}}$ during 1991 to 1995 was $17.1 \mathrm{~kg} \mathrm{~kg}^{-1}$ in $\mathrm{N}_{2}$ and $8.2 \mathrm{~kg}$ $\mathrm{kg}^{-1}$ in $\mathrm{N}_{3}$ treatments, but no consistent effects of the fallow periods on $A E_{N}$ were observed. The $\mathrm{RE}_{\mathrm{N}}$ in the WS crops ranged from 0.42 to $0.78 \mathrm{~kg} \mathrm{~kg}^{-1}$ in $\mathrm{N}_{2}$ and from 0.31 to $0.76 \mathrm{~kg} \mathrm{~kg}^{-1}$ in $\mathrm{N}_{3}$ (Table 2).

That the timing of $\mathrm{N}$ topdressings was more congruent with crop demand in the 1992 to 1995 DS compared with the late phase of the yield decline period is consistent with measurement of greater plant $\mathrm{N}$ accumulation, more efficient $A E_{N}$ and $\mathrm{RE}_{\mathrm{N}}$, optimal $\mathrm{IE}_{\mathrm{N}}$ in $\mathrm{N}_{2}$ and $\mathrm{N}_{3}$ treatments (Fig. 5), and the increased slope of the $\mathrm{N}$ response functions (Fig. 6). We presume that the greater precision of $\mathrm{N}$ management reduced $\mathrm{N}$ losses from the applied fertilizer from volatilization and denitrification (Fillery et al., 1986; Buresh and De Datta, 1990). Previous work at IRRI has shown that reducing the proportion of total $\mathrm{N}$ fertilizer applied at planting and increasing the number of $\mathrm{N}$ topdressings can result in significant improvements in $\mathrm{AE}_{\mathrm{N}}$, yield, and protein content of rice (Cassman et al., 1994; Peng et al., 1996; Perez et al., 1996). Other factors that may have contributed to greater fertilizer-N efficiency after 1991 include better control of floodwater depth in combination with greater precision in the timing of $\mathrm{N}$ application (particularly at PI and flowering stages) and prophylactic treatment for sheath blight and stemborer.

\section{Contribution of Different Factors to the Yield Reversal}

Because changes in management practices after 1991 were coincident with changes in climatic factors that influenced crop yields, the separate contributions of climate and management factors to the yield reversal were estimated for IR72, which was the only variety grown throughout the 1989 to 1995 period. Comparison of potential and actual grain yields of IR72 during this period allows partitioning of the effects of climate, increased $\mathrm{N}$ rate, greater $\mathrm{N}$ use efficiency, and dry fallow periods using the following approach for the DS:

$$
\begin{aligned}
\mathrm{YR}_{\mathrm{T}} & =\mathrm{YN}_{3 \mathrm{~b}}-\mathrm{YN}_{3 \mathrm{a}}=8.63-6.38=2.25 \mathrm{Mg} \mathrm{ha}^{-1} \\
\mathrm{YR}_{\mathrm{C}} & =\mathrm{Ymax}_{\mathrm{b}}-\mathrm{Ymax}_{\mathrm{a}}=9.57-8.37 \\
& =1.20 \mathrm{Mg} \mathrm{ha}^{-1} \\
\mathrm{YR}_{\mathrm{N}} & =\mathrm{YN}_{3 \mathrm{~b}}-\mathrm{YN}_{2 \mathrm{~b}}=8.63-8.26=0.37 \mathrm{Mg} \mathrm{ha}^{-1} \\
\mathrm{YR}_{\mathrm{R}} & =\mathrm{YR}_{\mathrm{T}}-\mathrm{YR}_{\mathrm{C}}-\mathrm{YR}_{\mathrm{N}} \\
& =2.25-1.20-0.37=0.68 \mathrm{Mg} \mathrm{ha}^{-1}
\end{aligned}
$$

where $\mathrm{YR}_{\mathrm{T}}$ is the total DS yield reversal compared with 1989 to $1991, Y_{R_{C}}$ is the yield reversal due to climate (solar radiation), $\mathrm{YR}_{\mathrm{N}}$ is the yield reversal due to increased $\mathrm{N}$ rate, $\mathrm{YR}_{\mathrm{R}}$ is the residual yield reversal due to other improvements in crop management, $\mathrm{Ymax}_{\mathrm{a}}$ is the average simulated potential yield of IR72 in 1989 to $1991, \mathrm{Ymax}_{\mathrm{b}}$ is the average simulated potential yield in 1992-1993, $\mathrm{YN}_{3 \mathrm{a}}$ is the average yield of IR72 in treatment $\mathrm{N}_{3}\left(150 \mathrm{~kg} \mathrm{~N} \mathrm{ha}^{-1}\right)$ in 1989 to $1991, \mathrm{YN}_{3 \mathrm{~b}}$ is the average yield of IR72 in treatment $\mathrm{N}_{3}\left(202 \mathrm{~kg} \mathrm{~N} \mathrm{ha}^{-1}\right)$ in 1992-1993, and $\mathrm{YN}_{2 \mathrm{~b}}$ is the average yield of IR72 in treatment $\mathrm{N}_{2}\left(135 \mathrm{~kg} \mathrm{~N} \mathrm{ha}^{-1}\right)$ in 1992-1993. Yields in the $\mathrm{N}_{2}$ and the $\mathrm{N}_{3}$ treatments increased similarly (Fig. 3 ), even though the $\mathrm{N}$ rate in the $\mathrm{N}_{2}$ treatment after the yield reversal $\left(\mathrm{YN}_{2 \mathrm{~b}}\right)$ was lower than the $\mathrm{N}$ rate in the $\mathrm{N}_{3}$ treatment before the yield reversal $\left(\mathrm{YN}_{3 \mathrm{a}}\right)$. Therefore, the only part of $\mathrm{YR}_{\mathrm{T}}$ that can be attributed to higher $\mathrm{N}$ rates is the difference $\mathrm{YN}_{3 b}-\mathrm{YN}_{2 b}$.

We performed similar calculations for the EWS crop, one for fallow years $(1991,1993$, and 1994) and one for nonfallow years (1992 and 1995), and compared both with the EWS crops during the 1989 to 1991 period. The $\mathrm{YR}_{\mathrm{T}}$ calculated as above was $2.66 \mathrm{Mg} \mathrm{ha}^{-1}$ in the fallow years and $1.75 \mathrm{Mg} \mathrm{ha}^{-1}$ in the nonfallow years. The net effect of climate and different transplanting dates was a $\mathrm{YR}_{\mathrm{C}}$ of $0.39 \mathrm{Mg} \mathrm{ha}^{-1}$ in fallow years and $0.89 \mathrm{Mg} \mathrm{ha}^{-1}$ in the nonfallow years. Applied $\mathrm{N}$ increased from $90 \mathrm{~kg} \mathrm{~N}^{-1}$ before the yield reversal to $105 \mathrm{~kg} \mathrm{~N} \mathrm{ha}^{-1}$ in $\mathrm{N}_{3}$ in the fallow years and to $115 \mathrm{~kg} \mathrm{ha}^{-1}$ in $\mathrm{N}_{3}$ in the nonfallow years. After the yield reversal, however, yields in the $\mathrm{N}_{2}$ treatment were higher than those in the $\mathrm{N}_{3}$ treatment in both fallow and nonfallow years $\left(\mathrm{YN}_{2 \mathrm{~b}}>\mathrm{YN}_{3 \mathrm{~b}}\right.$, Table 2). Hence, there was no contribution of $\mathrm{YR}_{\mathrm{N}}$ to the yield reversal in the EWS $\left(\mathrm{YR}_{\mathrm{N}}=0\right)$ so that $\mathrm{YR}_{\mathrm{R}}$ was $2.27 \mathrm{Mg} \mathrm{ha}{ }^{-1}$ in the fallow years and $0.85 \mathrm{Mg} \mathrm{ha}^{-1}$ in the nonfallow years. We attribute the difference between these two numbers $\left(1.42 \mathrm{Mg} \mathrm{ha}^{-1}\right)$ to the effect of fallow on $\mathrm{YR}_{\mathrm{T}}$, whereas the $\mathrm{YR}_{\mathrm{R}}$ in nonfallow years $\left(0.85 \mathrm{Mg} \mathrm{ha}^{-1}\right)$ resulted solely from improved crop management.

Summarizing, in the DS, $54 \%$ of $\mathrm{YR}_{\mathrm{T}}$ was due to climate (increase in solar radiation), $16 \%$ to the increase in $\mathrm{N}$ rate, and $30 \%$ to other improvements in crop management. In years with a fallow period before the WS, $15 \%$ of $\mathrm{YR}_{\mathrm{T}}$ in the WS was due to climate, $53 \%$ due to the fallow, and $32 \%$ due to other improvements in crop management. In years with the normal triple-crop system, $51 \%$ of $\mathrm{YR}_{\mathrm{T}}$ in the EWS was due to climate and $49 \%$ due to improvements in crop management.

It is possible that the relative contribution of climate to $\mathrm{YR}_{\mathrm{T}}$ was overestimated by using the 1989 to 1991 
baseline period, because solar radiation was unusually low in these years (Fig. 3). The $\mathrm{YR}_{\mathrm{C}}$ as defined above was greater than if we had used mean daily solar radiation values for the entire late phase of the yield decline, from 1980 to 1991, for comparison with the 1992 to 1995 period. This was not possible, however, because IR72 was not grown before 1989, and the ORYZA simulation model requires genoptype-specific coefficients to estimate potential yields.

In all cropping seasons, improvements in crop management $\left(\mathrm{YR}_{\mathrm{R}}\right)$ contributed 30 to $49 \%$ to the yield reversal. The two major changes in crop management occurring after the 1991 DS were (i) increased number and better timing of $\mathrm{N}$ topdressings and (ii) prophylactic control of diseases and stemborer (Table 1). The specific contribution to $\mathrm{YR}_{\mathrm{T}}$ from the changes in pest management practices cannot be estimated because detailed observations and measurements of incidence and severity of insect and disease damage were not made before 1991 and no unsprayed control plots were included after 1991. However, our previous analysis suggested that pests were not a major factor involved in the yield decline until 1991 (Cassman et al., 1995). The yield trends shown in Figure 4 are based on the highest-yielding variety in each season so that a possible breakdown in yielding ability or resistance to pests of one variety does not affect this time series. Diseases such as sheath blight may cause significant yield losses in high-N treatments, but rarely at the yield levels observed in the LTCCE during the late 1980s (Cu et al., 1996). During 1991 to 1995, yield losses due to pests and other factors were generally small. Therefore, also considering the high $\mathrm{N}$ use efficiencies (Table 2, Fig. 5), we argue that $Y_{R}$ mainly represents the yield increase achieved by improved congruence between $\mathrm{N}$ supply and crop $\mathrm{N}$ demand; i.e., better splitting and timing of $\mathrm{N}$ applications.

\section{GENERAL DISCUSSION}

The search for causal relationships explaining the yield decline in the LTCCE was made difficult by the lack of detailed data on plant performance and soil properties before 1991. When a yield decline was first recognized in long-term experiments at IRRI, a buildup of soil-related problems such as B toxicity and Zn deficiency due to irrigation with alkaline groundwater was proposed as a possible cause (Ponnamperuma, 1979; Flinn and De Datta, 1984). About 10 yr later, nine possible causes of the yield decline were identified: (1) a reduction in genetic yield potential of more recently released varieties, (2) climate change, (3) long-term changes in the chemistry of submerged soil affecting soil nutrient supply, (4) reduction in soil $\mathrm{N}$ supply due to changes of soil organic matter quality, (5) changes in soil and floodwater microbiology, (6) deficiencies or toxicities of nutrients other than $\mathrm{N}$ (such as $\mathrm{Zn}$ and B), (7) reduction of $\mathrm{N}$ uptake rates due to root-feeding nematodes, (8) decreasing soil bulk density and rooting volume, and (9) increasing insect and disease pressure due to continuous cropping (Cassman et al., 1995, 1997). It was also speculated that a depletion of plant-available soil Si caused the yield decline (Savant et al., 1997), but recently measured plant $\mathrm{Si}$ concentrations of 66 to $95 \mathrm{~g}$ $\mathrm{kg}^{-1}$ in the straw at maturity confirmed that $\mathrm{Si}$ is not a limiting factor to rice growth at the LTCCE site (A. Dobermann, unpublished data, 1999).

A decline in the INS due to structural changes and conservation of soil organic matter (cause 4 above) was proposed as a major soil process contributing to the gradual yield decline. The DS yield without applied N decreased by about $2.0 \mathrm{Mg} \mathrm{ha}^{-1}$ between 1968 and 1972 (Fig. 4). A yield decrease in $\mathrm{N}_{0}$ treatments of this magnitude represents a reduction in plant $\mathrm{N}$ accumulation from indigenous sources of about $25 \mathrm{~kg} \mathrm{~N} \mathrm{ha}^{-1} \mathrm{crop}^{-1}$. The cause of this decrease and whether it has equally occurred in the $\mathrm{N}_{1}$ to $\mathrm{N}_{3}$ treatments remains to be determined, but it is not associated with a decline in soil organic matter content (Cassman et al., 1995). Followup studies on characterization of two soil organic matter fractions, representing about $20 \%$ of the total soil organic matter content, confirmed the increasingly less humified nature of soil organic matter under increasing intensity of irrigated rice cropping. Accumulation of phenolic compounds in the youngest humus fractions appears to occur in soils that remain flooded and anoxic throughout most of the year as in the LTCCE (Olk et al., 1996, 1998, 1999). Increased phenol content of humic acid fractions may reduce the rate of $\mathrm{N}$ mineralization per unit of organically bound $\mathrm{N}$ in the soil (Olk et al., 1996), but a relationship between soil $\mathrm{N}$ mineralization and organic matter composition has not been established yet.

Our recent observations and measurements in the LTCCE also provide insight about the role of other putative causes of yield decline. While genotype and climate affected seasonal fluctuations and short-term trends in yield observed in the LTCCE, these factors do not explain the long-term yield decline from 1970 to 1991 (Fig. 4). Likewise, our observations during the period of yield increase (1991-1995) do not support the hypothesis that B toxicity or $\mathrm{Zn}$ deficiency had much effect on the yield decline or its reversal. The irrigation water source has not been changed during the course of the LTCCE and is not among those known for occasional high $\mathrm{B}$ concentrations at the experimental site (Cayton, 1985). Using the same irrigation water supply, it was possible to achieve increased yields after 1991. Seedling beds were treated with a $\mathrm{ZnO}$ suspension before transplanting from 1981 to 1989 . Despite this treatment, which is effective for alleviating $\mathrm{Zn}$ deficiency at the IRRI farm, there was no reversal of the yield decline during this period. Zinc sulfate was first applied in 1994, but yields approaching potential levels had already been realized in 1992 and 1993. Therefore, $\mathrm{Zn}$ deficiency does not appear to be a contributing factor to the yield decline.

In addition to the climatic effects, improved crop $\mathrm{N}$ supply was the major factor responsible for increased rice yields after 1991, providing new evidence that the yield decline observed until 1991 was caused by a gradual decline in $\mathrm{N}$ uptake and $\mathrm{N}$ use efficiency. Three factors may have contributed to the improved $\mathrm{N}$ nutri- 
tion associated with the yield reversal: (i) increased $\mathrm{N}$ supply from fertilizer to the root system (increased $\mathrm{N}$ rate and timing of $\mathrm{N}$ topdressings more congruent with crop demand), (ii) increased $\mathrm{N}$ supply to the root system from indigenous sources (increased $\mathrm{N}$ mineralization), or (iii) increased root $\mathrm{N}$ uptake capacity (improved root health and alleviation of other abiotic or biotic stresses affecting root $\mathrm{N}$ uptake). Although we did not measure root $\mathrm{N}$ uptake rates or other parameters of root health (iii), the changes in crop management probably had little impact on root development or function in the DS or in the WS in years when triple cropping was practiced.

Greater $\mathrm{N}$ use efficiency was achieved by reducing the amount of $\mathrm{N}$ applied at planting, by using a greater number of $\mathrm{N}$ topdressings (including a late $\mathrm{N}$ application at heading in the DS), and through changes in other aspects of crop management, such as prophylactic pest control. We caution, however, that the $\mathrm{N}$ response functions shown in Fig. 6 may not show the true change in $\mathrm{N}$ use efficiency over time, because they are based on fixed-location $\mathrm{N}$ treatment plots. It is common practice to estimate $\mathrm{N}$ response functions across $\mathrm{N}$ levels in a long-term experiment, but for studying changes over time, this assumes no residual effect of the respective $\mathrm{N}$ treatments on the indigenous $\mathrm{N}$ supply; i.e., any change that occurs in the $\mathrm{N}_{0}$ plots (intercept, $\mathrm{YN}_{0}$ ) is due to a process that occurs equally in the $\mathrm{N}_{1}$ to $\mathrm{N}_{3}$ treatments. The lack of an appropriate control $\mathrm{N}_{0}$ treatment to allow estimation of the INS in treatments with different fertilization history is a major limitation of current experimental designs for long-term studies that seek to quantify changes in response to fertilizer inputs over time and identify the causes for such changes.

With regard to the INS, soil drying during fallow periods increased $\mathrm{N}$ mineralization (INS) and contributed to the restoration of the grain yields in the WS of years when only two crops were grown. Enhanced soil aeration or soil drying is known to increase $\mathrm{N}$ mineralization (van Gestel et al., 1993). In our case, it is likely that this has caused a more complete decomposition of soil organic matter in years with double cropping and reduced the proportion of $\mathrm{N}$ stored in organic pools that contribute little to the available $\mathrm{N}$ supply for uptake by rice. Recent studies in an experiment located adjacent to the LTCCE on the same soil type have demonstrated enhanced $\mathrm{C}$ and $\mathrm{N}$ mineralization due to dry soil tillage after harvest coupled with a dry fallow period of two months. In this tillage system, there was an increase in the INS and rice $\mathrm{N}$ accumulation, particularly during the vegetative growth stage (Witt et al., 1998). However, the dry fallow effect was short-term in the LTCCE; it had no residual effect on subsequent DS rice crops, and the INS returned to levels that were considerably lower than in the early years of the experiment. In crop cycles that did not follow a dry fallow, $\mathrm{N}$ accumulation in $\mathrm{N}_{0}$ remained relatively constant at 50 to $60 \mathrm{~kg} \mathrm{~N} \mathrm{ha}^{-1}$ (Fig. 1). This amount of $\mathrm{N}$ is comparable to the estimated $\mathrm{N}$ contributions of $56 \mathrm{~kg} \mathrm{~N} \mathrm{ha}^{-1} \mathrm{crop}^{-1}$ from biological $\mathrm{N}_{2}$ fixation in the soil-floodwater system, irrigation water, and atmospheric inputs (Cassman et al., 1995), so the soil $\mathrm{N}$ balance may have reached an equilibrium.
It remains to be seen whether rice yields in the LTCCE can be maintained at levels close to the climateand genotype-specific yield potential, because the underlying mechanisms causing long-term changes in rice yield and in the response to $\mathrm{N}$ need further clarification. If there was a decline in INS or any other gradual change in soil processes that affect morphological or physiological characteristics of the root system related to $\mathrm{N}$ uptake, we did not mitigate the cause of this process over a longer time period, but only the outcome, by adjusting the timing and amount of applied $\mathrm{N}$ and through shortterm increases in INS due to soil drying. Moreover, although reducing cropping intensity from three to two rice crops per year coupled with a dry fallow period improved the INS in the LTCCE, which indicates the potential to reduce $\mathrm{N}$ fertilizer requirements, on an annual basis, total rice yields were about $4 \mathrm{Mg} \mathrm{ha}^{-1} \mathrm{yr}^{-1}$ lower in double-cropping years than in triple-cropping years (see Treatment $\mathrm{N}_{2}$ in Table 3). At issue, then, is how often soils in a triple-cropped rice system should be drained or fallowed to enhance soil organic matter turnover, reoxidize reduced compounds, and optimize both yield and $\mathrm{N}$ fertilizer use efficiency without sacrificing a major reduction in total rice production over the long term.

\section{ACKNOWLEDGMENTS}

We thank Mr. J. Alcantara for managing the LTCCE at IRRI from 1991 to 1995 and processing most of the samples and data collected, Mr. E. Laureles for providing us with data and searching the crop logbooks, and Ms. J.M.C.A. Cabrera for assistance in crop simulation modeling and statistical analysis.

\section{REFERENCES}

Boogaard, H.L., C.A. van Diepen, R.P. Roetter, J.M.C.A. Cabrera, and H.H. van Laar. 1998. WOFOST 7.1. User's guide for the WOFOST crop growth simulation model and WOFOST control center 1.5. Technical Document 52. DLO Winand Staring Centre, Wageningen, Netherlands.

Bremner, J.M., and C.S. Mulvaney. 1982. Nitrogen-Total. p. 595-623. In A.L. Page et al. (ed.) Methods of soil analysis. Part 2. Chemical and microbiological properties. 2nd ed. Agron. Monogr. 9. ASA and SSSA, Madison, WI.

Buresh, R.J., and S.K. De Datta. 1990. Denitrification losses from puddled rice soils in the tropics. Biol. Fert. Soils 9:1-13.

Cassman, K.G., S.K. De Datta, D.C. Olk, J. Alcantara, M. Samson, J.P. Descalsota, and M. Dizon. 1995. Yield decline and the nitrogen economy of long-term experiments on continuous, irrigated rice systems in the tropics. p. 181-222. In R. Lal and B.A. Stewart (ed.) Soil management: Experimental basis for sustainability and environmental quality. CRC Press, Boca Raton, FL.

Cassman, K.G., H.C. Gines, M. Dizon, M.I. Samson, and J.M. Alcantara. 1996. Nitrogen-use efficiency in tropical lowland rice systems: Contributions from indigenous and applied nitrogen. Field Crops Res. 47:1-12.

Cassman, K.G., M.J. Kropff, and Y.Z. De. 1994. A conceptual framework for nitrogen management of irrigated rice in high-yield environments. p. 81-96. In S.S. Virmani (ed.) Hybrid rice technology: New developments and future prospects. IRRI, Manila, Philippines.

Cassman, K.G., D.C. Olk, and A. Dobermann. 1997. Scientific evidence of yield and productivity declines in irrigated rice systems of tropical and subtropical Asia. FAO Int. Rice Comm. Newsl. 46:7-18.

Cassman, K.G., S. Peng, D.C. Olk, J.K. Ladha, W. Reichardt, A. Dobermann, and U. Singh. 1998. Opportunities for increased nitro- 
gen use efficiency from improved resource management in irrigated rice systems. Field Crops Res. 56:7-38.

Cassman, K.G., and P.L. Pingali. 1995. Extrapolating trends from long-term experiments to farmers' fields: The case of irrigated rice systems in Asia. p. 64-84. In V. Barnett et al. (ed.) Agricultural sustainability in economic, environmental, and statistical terms. J. Wiley \& Sons, London.

Cayton, M.T.C. 1985. Boron toxicity in rice. IRRI Res. Paper Ser. 13. IRRI, Manila, Philippines.

Cu, R.M., T.W. Mew, K.G. Cassman, and P.S. Teng. 1996. Effect of sheath blight on yield in tropical, intensive rice production system. Plant Disease 80:1103-1108.

Dawe, D., A. Dobermann, P. Moya, S. Abdulrachman, B. Singh, P. Lal, S.Y. Li, B. Lin, G. Panaullah, O. Sariam, Y. Singh, A. Swarup, P.S. Tan, and Q.X. Zhen. 2000. How widespread are yield declines in long-term rice experiments in Asia? Field Crops Res. 66:175-193.

Fillery, I.R.P., J.R. Simpson, and S.K. De Datta. 1986. Contribution of ammonia volatilization to total nitrogen loss after applications of urea to wetland rice fields. Fert. Res. 8:193-202.

Flinn, J.C., and S.K. De Datta. 1984. Trends in irrigated-rice yields under intensive cropping at Philippine research stations. Field Crops Res. 9:1-15.

IRRI. 1967. Annual report for 1966. IRRI, Manila, Philippines.

Kropff, M.J., H.H. van Laar, and H.F.M. ten Berge. 1993. ORYZA1. A basic model for irrigated lowland rice production. IRRI, Manila, Philippines.

Olk, D.C., G. Brunetti, and N. Senesi. 1999. Organic matter in doublecropped lowland rice soils: Chemical and spectroscopic properties. Soil Sci. 164:633-649.

Olk, D.C., K.G. Cassman, N. Mahieu, and E.W. Randall. 1998. Conserved chemical properties of young soil humic acid fractions in tropical lowland soils under intensive irrigated rice cropping. Eur. J. Soil Sci. 49:337-349.

Olk, D.C., K.G. Cassman, E.W. Randall, P. Kinchesh, L.J. Sanger, and J.M. Anderson. 1996. Changes in chemical properties of soil organic matter with intensified rice cropping in tropical lowland soils. Eur. J. Soil Sci. 47:293-303.

Peng, S., F.V. Garcia, R.C. Laza, A.L. Sanico, R.M. Visperas, and K.G. Cassman. 1996. Increased N-use efficiency using a chlorophyll meter on high-yielding irrigated rice. Field Crops Res. 47:243-252.

Perez, C.M., B.O. Juliano, S.P. Liboon, J.M. Alcantara, and K.G. Cassman. 1996. Effects of late nitrogen fertilizer application on head rice yield, protein content, and grain quality of rice. Cereal Chemistry 73:556-560.

Ponnamperuma, F.N. 1979. Soil problems in the IRRI farm. IRRI Thursday Seminar, 8 Nov. 1979. Mimeo. paper. IRRI, Manila, Philippines.

Savant, N.K., L.E. Datnoff, and G.H. Snyder. 1997. Depletion of plant-available silicon in soils: A possible cause of declining yields. Commun. Soil Sci. Plant Anal. 28:1245-1252.

Soil Survey Staff. 1994. Keys to soil taxonomy. SMSS Technical Monogr. 19. 6th ed. USDA-SCS, Washington, DC.

van Diepen, C.A., J. Wolf, H. van Keulen, and C. Rappoldt. 1989. WOFOST: A simulation model of crop production. Soil Use Manage. 5:16-24

van Gestel, M., R. Merckx, and K. Vlassak. 1993. Microbial biomass responses to soil drying and rewetting: The fate of fast- and slowgrowing microorganisms in soils from different climates. Soil Biol. Biochem. 25:109-123.

Witt, C., K.G. Cassman, J.C.G. Ottow, and U. Biker. 1998. Soil microbial biomass and nitrogen supply in an irrigated lowland rice soil as affected by crop rotation and residue management. Biol. Fert. Soils 28:71-80.

Witt, C., A. Dobermann, S. Abdulrachman, H.C. Gines, G.H. Wang, R. Nagarajan, S. Satawathananont, T.T. Son, P.S. Tan, L.V. Tiem, G.C. Simbahan, and D.C. Olk. 1999. Internal nutrient efficiencies of irrigated lowland rice in tropical and subtropical Asia. Field Crops Res. 63:113-138. 